\section{Antimicrobial activity of olive mill wastewater extract against Pseudomonas fluorescens iso- lated from mozzarella cheese}

\author{
Rossana Roila, ${ }^{1}$ Raffaella Branciari, ${ }^{2}$ \\ David Ranucci, ${ }^{2}$ Roberta Ortenzi, ${ }^{1}$ \\ Stefania Urbani, ${ }^{3}$ Maurizio Servili, ${ }^{3}$ \\ Andrea Valiani ${ }^{1}$ \\ ${ }^{1}$ Institute for Experimental Veterinary \\ Medicine of Umbria and Marche, Perugia; \\ 2Department of Veterinary Medicine, \\ University of Perugia, Perugia; \\ ${ }^{3}$ Department of Agricultural, Food, and \\ Environmental Sciences, University of \\ Perugia, Perugia, Italy
}

\section{Abstract}

Olive mill wastewater polyphenol extract was tested for antimicrobial activity against 64 strains of Pseudomonas fluorescens responsible for mozzarella discolouration. The extract showed a minimum inhibitory concentration $(\mathrm{MIC})_{50}$ value of $5 \mathrm{mg} / \mathrm{mL}$ and a $\mathrm{MIC}_{90}$ value of $7 \mathrm{mg} / \mathrm{mL}$. The $\mathrm{MBC}_{50}$ and $\mathrm{MBC}_{90}$ values corresponded to 6 and $8 \mathrm{mg} / \mathrm{mL}$, respectively. The MIC concentration $(7 \mathrm{mg} / \mathrm{mL})$ was demonstrated to have a bacteriostatic effect while maintaining the bacterial concentration on the levels of the inoculum for 48 hours. The $3 / 2$ MIC concentration was responsible for four logs $\mathrm{CFU} / \mathrm{mL}$ depletion in colony count after $24 \mathrm{~h}$. As the extract concentration decreased from MIC value, no inhibitory effects were recorded.

\section{Introduction}

Microbial spoilage is a major concern in the food industry, as microbial contamination and growth can result in undesirable changes in appearance, texture, flavour and odour that reduce food quality or cause food loss (Sperber and Doyle, 2009). The Pseudomonas spp. group is strictly connected to food spoilage, especially for animal-derived foods like meat, poultry, milk and fish, and its importance is related to the food trade and hygienic standards (Liao, 2006). Because of the psychrotrophic and mesophilic characteristics of these bacteria, they can replicate at refrigeration temperatures, and long periods of shelf-life can easily increase the Pseudomonas concentration in food (Andreani et al., 2014; Marchand et al., 2009; Munsch-Alatossava et al., 2005). Specifically, Pseudomonas fluorescens represents part of the main microflora of raw milk and dairy products that can be contaminated via defiled water and soil, inadequately sanitised milking surfaces, storage and transporting equipment (Munsch-Alatossava et al., 2005; Chiesa et al., 2014). Heat-stable lipases and proteases produced by Pseudomonas fluorescens and other similar pseudomonads are a cause of milk spoilage and are responsible of casein breakdown, bitterness and ropiness due to the production of slime and coagulation of proteins (Jay, 2000).

Interest in the aforementioned bacteria in dairy products increased after the case of blue mozzarella that occurred in 2010 when some European consumers noted a blue discolouration on some mozzarella products (Martin et al., 2011; Andreani et al., 2014). This colour change was due to the production by $P$. fluorescens: under certain conditions, a blue, nondiffusible pigment as well as the soluble pigment pyoverdin fluoresces under UV light. Despite all the efforts made by mozzarella manufacturers to avoid or minimise contamination, it is difficult to eradicate $P$. fluorescens even with extraordinary sanitation processes due to its remarkable adaptability and ability to produce biofilm (Sperber and Doyle, 2009). Hence, there is a strong need for alternative methods that are able to limit bacterial growth during the product's shelf-life.

Currently, there is a worldwide effort to minimise the use of chemical preservatives because of consumer preferences towards more natural and healthier products. Consequently, we are seeing an increasing scientific interest in the search for natural antimicrobial compounds like biopreservatives (Serra et al., 2008). In recent decades, research has shown the potential exploitation of plant products as a bioactive compound source of industrial interest (Prado Martin et al., 2013). The application of natural antimicrobial compounds in food could be useful to prevent the growth of spoilage microorganisms such as Pseudomonas spp. (Gammariello et al., 2008). Different by-products derived from olive oil extraction process are reach in phenolic compounds (PC), which have demonstrated possible application in feed and food industry (Branciari et al., 2015). Among natural products, olive-mill wastewater (OMW), a by-product of the olive oil extraction process, could be an alternative source for biologically active phenols compounds that can be used in the food industry. The phenol substances present in OMW are aglycon derivatives: the dialdheydic form of decarboxymethyl elenolic acid linked to 3,4-DHPEA or p-HPEA (3,4-DHPEAEDA or p-HPEA-EDA), the isomer of oleuropein aglycon (3,4-DHPEA-EA), the lygstroside aglycon (p-HPEA-EA) and the hydroxycinnamic acid derivative verbascoside (Servili et al., 2011). These substances are proven to inhibit or delay the rate of growth of a range of bacte-
Correspondence: David Ranucci, Department of Veterinary Medicine, University of Perugia, via San Costanzo 4, 06126 Perugia (PG), Italy. Tel: +39.075.5857931 - Fax: +39.075.5857928.

E-mail: david.ranucci@unipg.it

Key words: Pseudomonas fluorescens; Olive mil wastewater; Polyphenols; Antibacterial; By-product.

Conflict of interest: the authors declare no potential conflict of interest.

Acknowledgements: this research was sponsored by Italian Ministry of Health, 2011 [grant no. RC009201, CUP-D97G12000160001: Impiego di estratti polifenolici ottenuti da acqua di vegetazione di oliva (Olea europaea) per il controllo di Pseudomonas fluorescens in formaggi freschi a pasta filata].

Received for publication: 20 January 2016.

Revision received: 21 March 2016.

Accepted for publication: 23 March 2016.

This work is licensed under a Creative Commons Attribution-NonCommercial 4.0 International License (CC BY-NC 4.0).

(C) Copyright R. Roila et al., 2016

Licensee PAGEPress, Italy

Italian Journal of Food Safety 2016; 5:5760

doi:10.4081/ijfs.2016.5760

ria, so that they may be used as alternative food additives (Pereira et al., 2006). The aim of the study is to evaluate antimicrobial activity of PC extracted from OMW against different $P$. fluorescens strains responsible of mozzarella discoloration.

\section{Materials and Methods}

Purification and evaluation of phenolic compound from olive mill wastewater

In order to obtain OMW rich in phenols to be used for the production of polyphenolic extract (PE), Italian Olea europeae cultivars with a high content of PC were selected (Moraiolo cultivar). The OMW PE was produced according to Servili et al. (2011). The PC evaluation was performed with high-performance liquid chromatography (HPLC) analysis using an Agilent Technologies Model 1100 consisting of a vacuum degasser, a quaternary pump, an autosampler, a thermostatted column compartment, a diode array detector (DAD) set at 278 nm (Esposto et al., 2015).

\section{Bacterial strains, culture media}

P. fluorescens ATCC 13525 and 64 strains of P. fluorescens stored in the Institute for 
Experimental Veterinary Medicine of Umbria and Marche collection (IZSUM-PF no. 259-299, 310-334) were tested to evaluate the antimicrobial effect of the PE; the 64 strains derived from fresh pasta filata cheeses that exhibited the blue pigment defect. The stored strains were revitalised on Brain Heart Infusion Broth (BHI; cod. 4012302; Biolife Italiana s.r.l., Milan, Italy), incubated at $25 \pm 1^{\circ} \mathrm{C}$ for 24 hours under aerobic conditions.

\section{Dilution of polyphenolic extract}

The PE, stored at $-20^{\circ} \mathrm{C}$ was characterised by a creamy consistency and had a colour between yellow and orange. The physical characteristics of the extract meant that it could not be used directly. For this reason, in order to increase the solubility of all its components, it was necessary to dilute it with an ethanol/water 60/40 (v/v) solution (mother solution, maintained at a temperature of $+4^{\circ} \mathrm{C}$ ). At the time of use, the mother solution was diluted again to obtain the concentration of polyphenols and ethanol required by the protocol for the evaluation of the antimicrobial effect. The ethanol used was purchased from Carlo Erba Reagents s.r.l. (cod. 414605; Milan, Italy).

\section{In vitro evaluation of antimicrobial effects of polyphenolic extract}

In order to test the antibacterial effect of $\mathrm{PE}$, minimum inhibitory (MIC) and minimum bactericidal (MBC) concentrations were determined. The tests were conducted using a standard microdilution technique according to Clinical Laboratory Standards Institute guidelines adapting the protocol as suggested by Othman et al. (2011).

The bacterial suspension to be used for the assay was prepared as previously reported, adjusting the number of bacteria to approximately $1 \times 10^{5} \mathrm{CFU} / \mathrm{mL}$ with fresh $\mathrm{BHI}$. The phenolic extract concentrations tested were 8, 7,6, 5,4 and $3 \mathrm{mg} / \mathrm{mL}$ of total PC. Moreover, for each bacterial strain four controls were set up. These included the antibacterial effect of ethanol (using the same concentrations already present in the extract), antibiotic control (with ciprofloxacin), organism control (wells containing BHI and the bacterial suspension), negative control (wells containing BHI and the solution of polyphenols at the same concentration tested).

At time 0 , the microplates were read in optical density at $620 \mathrm{~nm}$ using a spectrophotometer (Multiskan FC Thermo Scientific, Vantaa, Finland) and immediately incubated for 18 to 20 hours at $25 \pm 1^{\circ} \mathrm{C}$ in aerobic conditions. After the incubation time the second reading at $620 \mathrm{~nm}$ was performed. MIC was defined as the lowest concentration of extract that produced no bacterial growth when compared to time 0 wells. MIC $_{50}$ a MIC $_{90}$ were defined as the extract concentration that inhibits 50 and $90 \%$ of the isolates, respectively. Moreover, in order to define the MBC, $100 \mu \mathrm{L}$ of the well's content was plated on Penicillin Piramicin Agar (PPA; cod. 4019602; Biolife Italiana S.r.l.) dishes then incubated for 24 hours at $25 \pm 1^{\circ} \mathrm{C}$ in aerobic conditions. The MBC was represented as the smallest amount of PE that was capable of killing the bacterial inoculum, demonstrated by the total absence of growth. $\mathrm{MBC}_{50}$ a $\mathrm{MBC}_{90}$ were defined as the extract concentration, which kills 50 and $90 \%$ of the isolates, respectively.

\section{In vitro evaluation of death kinetics of Pseudomonas fluorescens with} different concentrations of

\section{polyphenolic extract}

The bacterial survival curve was studied over a range of multiples MICs, 1/10 MIC, 1/5 MIC, 1/2 MIC, MIC, 3/2 MIC on four randomly selected strains of $P$. fluorescens already tested for the evaluation of antimicrobial effect of PE. The assay was carried out based on the method reported by Bubonja-Sonje et al. (2011) with some modifications. The stored strains were revitalised in $\mathrm{BHI}$ incubated at $25 \pm 1^{\circ} \mathrm{C}$ for 24 $48 \mathrm{~h}$ under aerobic conditions. The bacterial suspensions were separately enumerated and pooled together before the inocolum. The starting inoculum was prepared adjusting it to approximately $1 \times 10^{5} \mathrm{CFU} / \mathrm{mL}$ with fresh $\mathrm{BHI}$ broth. Sterile 96-well microtiter plates were added with $80 \mu \mathrm{L}$ of inoculum and $80 \mu \mathrm{L}$ of extract to produce final concentration equivalent to 1/10 MIC, 1/5 MIC, 1/2 MIC, MIC, 3/2 MIC; negative (wells containing $\mathrm{BHI}$ ) and positive (wells containing $\mathrm{BHI}$ and bacterial suspension) controls were also included.

The plates were incubated at $25 \pm 1^{\circ} \mathrm{C}$ and, at predetermined time points $(0,3,9,12,24,48$ h), a $100 \mu \mathrm{L}$ sample was removed from each well with test suspension, 10 -fold serially diluted in sterile peptone water (cod. A1702HA; Diagnostic International Distribution s.p.a., Milan, Italy) and plated on PPA for colony count determination. The experiment was performed in duplicate and replicated three times, and the data obtained were averaged and plotted as $\log$ CFU/mL $v$ s time. Growth curves of $P$. fluorescens pooled strains, under different extract concentrations, were built using DMFit version 2015 (ComBase online freeware) by fitting data to the Baranyi and Robertes's model (Baranyi and Roberts, 1994). From the obtained curves, the duration of lag phase $(\lambda)$, maximum growth rate $\left(\mu_{\max }\right)$ and final value were calculated. Data were then compared by one-way ANOVA followed by post hoc Tukey tests. The significance were set at $\mathrm{P}<0.05$. When bacteria were not detected at the level of $1.0 \log \mathrm{CFU} / \mathrm{mL}$, a value of $-0.5 \log \mathrm{CFU} / \mathrm{mL}$ was assigned (Ranucci et al., 2014).

\section{Results and Discussion}

\section{Polyphenolic extract composition}

The content of each PC of the extract was characterised by $12.3 \pm 0.4 \mathrm{mg} / \mathrm{g}$ of $\mathrm{p}$-HPEA (tyrosol), $56.5 \pm 1.1 \mathrm{mg} / \mathrm{g}$ of 3,4 DHPEA (hydroxytyrosol), $80.0 \pm 4.1 \mathrm{mg} / \mathrm{g}$ of verbascoside and $532.5 \pm 9.8$ of 3,4 DHPEA-EDA. The total amount of PC corresponded to $681.3 \pm 10.7 \mathrm{mg} / \mathrm{g}$ (Figure 1 and Table 1).

In the extract used, the most represented molecule was 3,4-DHPEA-EDA. Furthermore, the variability of phenols content in $0 \mathrm{MW}$ is reported in literature (Dermeche et al., 2013).

Table 1. Phenolic compounds detected on the olive mill wastewater polyphenol extract.

\begin{tabular}{|c|c|c|c|}
\hline Compounds & $\mathrm{m} / \mathrm{z}$ & Molecular formula & References \\
\hline 3,4-DHPEA hydroxytyrosol & 153 & $\mathrm{C}_{8} \mathrm{H}_{10} \mathrm{O}_{3}$ & $\begin{array}{l}\text { Di Maio et al. (2011); } \\
\text { De Marco et al. (2007) }\end{array}$ \\
\hline p-HPEA Tyrosol & 137 & $\mathrm{C} 8 \mathrm{H}_{10} \mathrm{O}_{2}$ & $\begin{array}{l}\text { Di Maio et al. (2011); } \\
\text { De Marco et al. (2007) }\end{array}$ \\
\hline 3,4-DHPEA-EDA & 377 & $\mathrm{C}_{19} \mathrm{H}_{22} \mathrm{O}_{8}$ & $\begin{array}{l}\text { Di Maio et al. (2013); } \\
\text { De Marco et al. (2007) }\end{array}$ \\
\hline Verbascoside & 623 & $\mathrm{C}_{9} \mathrm{H}_{36} \mathrm{O}_{15}$ & $\begin{array}{l}\text { De Marco et al. (2007); } \\
\text { Obied et al. (2007); } \\
\text { Dermeche et al. (2013) }\end{array}$ \\
\hline
\end{tabular}


The differences in the extract composition may vary greatly depending on factors such as cultivar, geographical origin, the ripening of the fruit, the milling technique and the extraction method (El-Abbassi et al., 2012; Pereira et al., 2006; Vinha et al., 2005; Dermeche et al., 2013).

\section{In vitro evaluation of antimicrobial effects of polyphenolic extract}

The antimicrobial effect of the PE was examined by broth microdilution susceptibility assay using different concentrations on 65 strains of $P$. fluorescens. The inhibitory effect of each of the six dilutions of PE tested $(3,4,5$, $6,7,8 \mathrm{mg} / \mathrm{mL}$ ) is reported in Table 2 . As shown, the $\mathrm{MIC}_{50}$ value was $5 \mathrm{mg} / \mathrm{mL}, \mathrm{MIC}_{90}$ was 7 $\mathrm{mg} / \mathrm{mL}$, and $\mathrm{MBC}_{50}$ and $\mathrm{MBC}_{90}$ values corresponded to 6 and $8 \mathrm{mg} / \mathrm{mL}$, respectively.

Differences in the antimicrobial effect among strains were registered, as shown in Table 2. Five $\mathrm{mg} / \mathrm{mL}$ of the extract killed the $15 \%$ of the strains tested, whereas the concentration able to kill $100 \%$ of the bacteria tested was $8 \mathrm{mg} / \mathrm{mL}$. Fasolato et al. (2015) found that bactericidal effect of PE was exerted when 6 $\mathrm{mg} / \mathrm{mL}$ was used, but only two $P$. fluorescens strains were tested. The composition of the extract could also influence the bacterial dynamics and resistance mainly for the difference in the compounds and their structure. Bisignano et al. (1999) reported higher MIC values for oleuropein than hydroxytyrosol tested on several ATCC bacteria, and Obied et al. (2007) found that the antibacterial effect against Gram+, Gram- bacteria and yeasts was exerted more by hydroxytyrosol than by oleuropein. Although both compounds have an o-diphenol system, which is responsible of antibacterial activity, these compounds have lower inhibitory effects than their products of hydrolysis (Medina et al., 2013). The antibacterial activity is mainly related to the dialdehydic form of decarboxymethyl elenoic acid, free or linked to tyrosol or hydroxytyrosol (Medina et al., 2009). The PE tested was characterised by a relative high amount of 3,4 DHPEA-EDA, in turn characterised by the elenolic acid structure linked to hydroxytirosol, which has a strong antimicrobial activity similar to that of commercial biocide (Medina et al., 2013).

The results obtained confirm that $P$. fluo- rescens exerts a certain resistance to both synthetic (Langsrud et al., 2003) and natural biocides (Fasolato et al., 2015; Medina et al. 2009), but they also show that not all the strains have the same resistance. Furthermore, Gutierrez-Larrainzar et al. (2013) tested synthetic PC (thymol, carvacrol, eugenol, hydroquinone, $p$-hydroxybenzoic acid and gallic acid) on P. fluorescens, and found a significant intraspecific variability for some of the molecules tested.

In vitro evaluation of death kinetics of Pseudomonas fluorescens with different concentrations of polyphenolic extract

The results of the death kinetic data and their estimation are reported in Figure 2 and Table 3 .

The use of different extract concentrations resulted in different levels of $P$. fluorescens inhibition.

The addition of the PE extract at 1/10 MIC showed no difference when compared to $\mathrm{PC}$ for all the parameters considered. A longer than

Table 2. Minimum bactericidal concentration and minimum inhibitory concentration of the polyphenolic extract for the sixty-five Pseudomonas fluorescens strains tested (number of strains and overall percentage).

\begin{tabular}{lcccc}
$\begin{array}{c}\text { Concentration } \\
(\mathrm{mg} / \mathrm{mL})\end{array}$ & $\begin{array}{c}\text { Number of strains } \\
\text { inhibited }\end{array}$ & $\begin{array}{c}\text { Percentage of strains } \\
\text { inhibited }\end{array}$ & $\begin{array}{c}\text { Number of strains } \\
\text { killed }\end{array}$ & $\begin{array}{c}\text { Percentage of strains } \\
\text { killed }\end{array}$ \\
\hline 8 & 65 & 100 & 65 & 100 \\
7 & 65 & 100 & 53 & 82 \\
\hline 6 & 53 & 82 & 36 & 55 \\
\hline 5 & 41 & 63 & 10 & 15 \\
3 & 11 & 17 & 0 & 0 \\
\hline
\end{tabular}

MIC, minimum inhibitory concentration; $\mathrm{MBC}$, minimum bactericidal concentration.

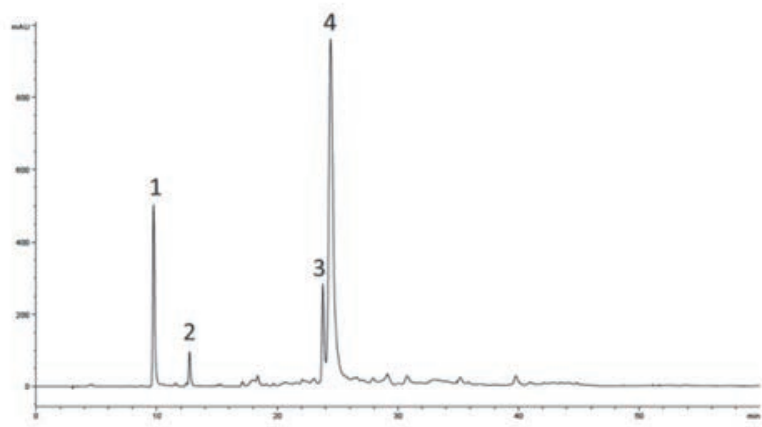

Figure 1. High-performance liquid chromatogram of the extract from olive mill wastewaters polyphenol recorded with diode array detector at $278 \mathrm{~nm}$. Peak numbers: 1 , hydroxytyrosol $(3,4-$ DHPEA); 2, tyrosol ( $p$-HPEA); 3, verbascoside; 4, dialdehydic form of decarboxymethyl elenolic acid linked to 3,4-DHPEA (3,4-DHPEA-EDA).

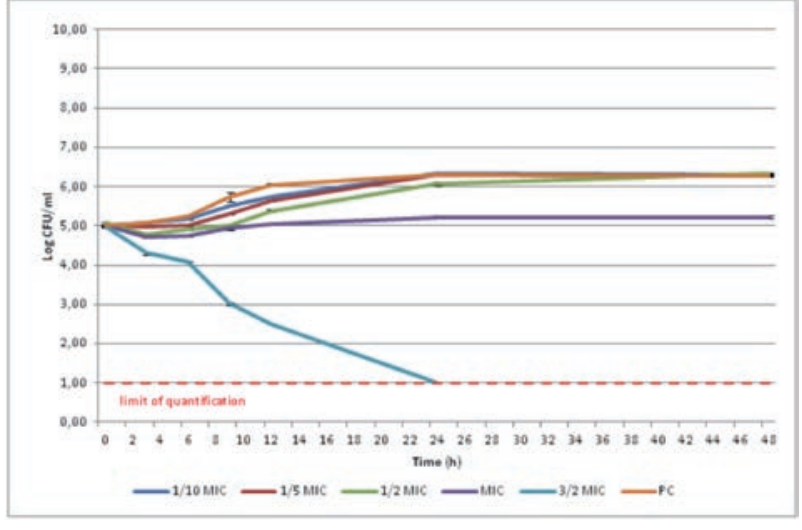

Figure 2. Growth of the Pseudomonas fluorescens strains with different concentrations of polyphenolic extract (average values for four pooled strains tested in triplicate \pm standard deviation). MIC, minimum inhibitory concentration; PC, phenolic compound. 
Table 3. Estimation of the death kinetic parameters using the Baranyi-Roberts model.

\begin{tabular}{|c|c|c|c|c|c|c|c|c|}
\hline & PC & 1/10 MIC & 1/5 MIC & 1/2 MIC & MIC & 3/2 MIC & SEM & $\mathbf{P}$ \\
\hline Initial value $(\log \mathrm{CFU} / \mathrm{mL})$ & 5.01 & 5.01 & 5.00 & 4.91 & 4.82 & 4.95 & 0.023 & 0.167 \\
\hline$\lambda(\mathrm{h})$ & $4.17^{\mathrm{b}}$ & $4.33^{\mathrm{b}}$ & $7.02^{\mathrm{c}}$ & $7.66^{\mathrm{c}}$ & $7.72^{c}$ & $0.94^{\mathrm{a}}$ & 1.089 & $<0.001$ \\
\hline$\mu_{\max }(\log \mathrm{CFU} / \mathrm{mL} / \mathrm{h})$ & $0.14^{c}$ & $0.10^{\mathrm{bc}}$ & $0.13^{\mathrm{c}}$ & $0.07^{\mathrm{b}}$ & $0.06^{\mathrm{b}}$ & $-0.22^{\mathrm{a}}$ & 0.055 & $<0.001$ \\
\hline Final value (Log CFU/mL) & $6.29 c$ & $6.31^{\mathrm{c}}$ & $6.28^{c}$ & $6.32^{c}$ & $5.22^{\mathrm{b}}$ & $-0.05^{\mathrm{a}}$ & 1.037 & $<0.001$ \\
\hline $\mathrm{R}^{2}$ value & 0.993 & 0.995 & 0.995 & 0.929 & $0.52^{4}$ & 0.942 & & \\
\hline SE of fit & 0.047 & 0.039 & 0.040 & 0.159 & 0.143 & 0.240 & & \\
\hline
\end{tabular}

PC, positive control; MIC, minimum inhibitory concentration; $\lambda$, lag phase; $\mu_{\max }$, maximum growth rate; SEM, standard error of mean; CFU, colony forming unit; SE, standard error. ${ }^{\text {a-c }}$ Different letters in the same row denote difference between the means $(\mathrm{P}<0.05)$

the PC was observed from 1/5 MIC onwards. Nevertheless, the $\mu_{\max }$ decreased only when the concentration used was higher than $1 / 2$ MIC. Despite these differences, the final values were similar among PC, 1/10 MIC, 1/5 MIC and 1/2 MIC, as confirmed in Figure 2 after 24 hours. As the extract concentration decreased from MIC value no inhibitory effects was recorded

The MIC concentration resulted in exthended $\lambda$ and reduced $\mu_{\max }$ compared to PC. Furthermore, the inoculum $P$. fluorescens concentration was similar to the final value (initial value $=4.82$ and final value $=5.22$ ). The $3 / 2$ MIC concentration had a noticeable effect on $P$. fluorescens death kinetics and was responsible for four logs $\mathrm{CFU} / \mathrm{mL}$ depletion in colony count after $24 \mathrm{~h}$, reaching the limit of quantification of the method (10 CFU/mL). At this concentration the $\mu_{\max }$ was negative and significantly different from the other concentration used. Furthermore, the value was the lowest recorded because this PE concentration has a lethal effect on the strains tested already after 3 hours. No study on bacterial death kinetics of PE on $P$. fluorescens is reported in the literature. Serra et al. (2008) described the study of bacterial growth kinetics in the presence of different concentrations of olive extract, showing no inhibition of growth for $E$. coli and poor inhibition for Salmonella pomona, while for Bacillus cereus the extract exerts a dose dependent inhibition. Servili et al. (2004) did not find a significant reduction on lactic bacteria growth of yogurt added with $0.1-0.2 \mathrm{mg} / \mathrm{mL}$ PE. The dose-dependent effect was observed also by Bubonja-Sonje $e t$ al. (2011), who tested total olive oil polyphenols on Listeria monocytogenes growth.

\section{Conclusions}

The OMW extract shows a dose-dependent antimicrobial effect against $P$. fluorescens, even though remarkable differences among the tested strains were observed. The results of the death kinetic study on $P$. fluorescens could be of utmost interest in the use of such compounds in limiting the growth of these spoilage bacteria. The use of this extract needs further investigation to better define the real potential of this promising natural preservative and its most suitable applications in food industry.

\section{References}

Andreani NA, Martino ME, Fasolato L, Carraro L, Montemurro F, Mioni R, Bordin P, Cardazzo B, 2014. Tracking the blue: a MLST approach to characterize the Pseudomonas fluorescens group. Food Microbiol 39:116-26.

Baranyi J, Roberts TA, 1994. A dynamic approach to predicting bacterial growth in food. Int J Food Microbiol 23:277-94.

Bisignano G, Tomaino A, Lo Cascio R, Crisafi G, Uccella N, Saija A, 1999. On the in-vitro antimicrobial activity of oleuropeina and hydroxytyrosol. J Pharm Pharmacol 51:971-4.

Branciari R, Ranucci D, Miraglia D, Urbani S, Esposto S, Servili M, 2015. Effect of dietary treatment with olive oil by-product (olive cake) on physico-chemical, sensory and microbial characteristics of beef during storage. Ital J Food Safety 4:5496.

Bubonja-Sonje M, Giacometti J, Maja Abram M, 2011. Antioxidant and antilisterial activity of olive oil, cocoa and rosemary extract polyphenols. Food Chem 127:1821-7.

Chiesa F, Lomonaco S, Nucera D, Garoglio D, Dalmasso A, Civera T, 2014. Distribution of Pseudomonas species in a dairy plant affected by occasional blue discoloration. Ital J Food Safety 3:1722.

De Marco E, Savarese M, Paduano A, Sacchi R, 2007. Characterization and fractionation of phenolic compounds extracted from olive oil mill wastewaters. Food Chem 104:858-67.

Dermeche S, Nadour M, Larroche C, MoultiMati F, Michaud P, 2013. Live mill wastes: biochemical characterizations and valorization strategies. Process Biochem 48:1532-52.
Di Maio I, Esposto S, Taticchi A, Selvaggini R, Veneziani G, Urbani S, Servili M, 2011. HPLC-ESI-MS investigation of tyrosol and hydroxytyrosol oxidation products in virgin olive oil. Food Chem 125:21-8.

Di Maio I, Esposto S, Taticchi A, Selvaggini R, Veneziani G, Urbani S, Servili M, 2013. Characterization of 3,4-DHPEA-EDA oxidation products in virgin olive oil by high performance liquid chromatography coupled with mass spectrometry. Food Chem 138:1381-91.

El-Abbassi A, Kiai H, Hafidi A, García-Payo MC, Khayet M, 2012. Treatment of olive mill wastewater by membrane distillation using polytetrafluoroethylene membranes. Sep Purif Technol 98:55-61.

Esposto S, Taticchi A, Di Maio I, Urbani S, Veneziani G, Selvaggini R, Sordini B, Servili M, 2015. Effect of an olive phenolic extract on the quality of vegetable oils during frying. Food Chem 176:184-92.

Fasolato L, Cardazzo B, Balzan S, Carraro L, Taticchi A, Montemurro F, Novelli E, 2015. Minimum bactericidal concentration of a phenols extract from oil vegetation water (PEOW) on food-borne bacteria. Ital J Food Safety 4:4519.

Jay JM, 2000. Taxonomy, role and significance of microorganisms in food. In: Jay JM, Loessner MJ, Golden DA, eds. Modern food microbiology. Aspen Publishers, Gaithersburg, MD, USA, p 13.

Gammariello D, Di Giulio S, Conte A, Del Nobile MA, 2008. Effects of natural compounds on microbial safety and sensory quality of Fior di Latte cheese, a typical Italian cheese. J Dairy Sci 91:4138-46.

Gutierrez-Larrainzar M, Rua J, de Arriaga D, del Valle P, Garcia-Armesto MR, 2013. In vitro assessment of synthetic phenolic antioxidants for inhibition of foodborne Staphylococcus aureus, Bacillus cereus and Pseudomonas fluorescens. Food Control 30:393-9.

Langsrud S, Sundheim G, Borgmann-Strahsen $\mathrm{R}, 2003$. Intrinsic and acquired resistance to quaternary ammonium compounds in food-related Pseudomonas spp. J Appl Microbiol 95:874-82. 
Liao $\mathrm{CH}, 2006$. Pseudomonas and related genera. In: Blackburn CW, ed. Food spoilage microorganisms. Woodhead Publishing, Boca Raton, FL, USA, pp 507-40.

Marchand S, Vandriesche G, Coorevits A, Coudijzer K, De Jonghe V, Dewettinck K, De Vos P, Devreese B, Heyndrickx M, De Block J, 2009. Heterogeneity of heat-resistant proteases from milk Pseudomonas species. Int J Food Microbiol 133:68-77.

Martin NH, Murphy SC, Ralyea RD, Wiedmann M, Boor KJ, 2011. When cheese gets the blues: Pseudomonas fluorescens as the causative agent of cheese spoilage. J Dairy Sci 94:2176-83.

Medina E, Brenes M, Garcia A, Romero C, De Castro A, 2009. Bactericidal activity of glutaraldehyde-like compounds from olive products. J Food Protect 72:2611-4.

Medina E, De Castro A, Romero C, Ramirez E, Brenes M, 2013. Effect of antimicrobial compounds from olive products on microorganisms related to health, food and agriculture. In: Méndez-Vilas A, ed. Microbial pathogens and strategies for combating them: science, technology and education. Formatex Research Center Publishing, Badajoz, Spain, pp 1087-94.

Munsch-Alatossava P, Alatossava T, 2005. Phenotypic characterization of raw milk- associated psychrotrophic bacteria. Microbiol Res 161:334-46.

Obied HK, Bedgood Jr DR, Prenzler PD, Robards K, 2007. Bioscreening of Australian olive mill waste extracts: biophenol content, antioxidant, antimicrobial and molluscicidal activities. Food Chem Toxicol 45:1238-48.

Othman M, Loh HS, Wiart C, Khoo TJ, Lim KH, Ting KN, 2011. Optimal methods for evaluating antimicrobial activities from plant extracts. J Microbiol Meth 84:161-6.

Pereira AJ, Pereira AP, Ferreira IC, Valentão P, Andrade PB, Seabra R, Estevinho L, Bento A, 2006. Table olives from Portugal: phenolic compounds, antioxidant potential and antimicrobial activity. J Agr Chem 54:842531 .

Prado Martin JG, Porto E, de Alencar SM, da Glória EM, Corrêa CB, Ribeiro Cabral IS, 2013. Antimicrobial activity of yerba mate (Ilex paraguariensis St. Hil.) against food pathogens. Rev Argent Microbiol 45:93.

Ranucci D, Branciari R, Miraglia D, Stocchi R, Rea S, Loschi AR, 2014. Evaluation of carcass hygiene in sheep subjected to gas depelting with different skinning procedures. Ital J Food Safety 3:4143.

Serra AT, Matias A, Nunes A, Leitão MC, Brito D, Bronze R, Silva S, Pires A, Crespo MT,
San Romão MV, Duarte CM, 2008. In vitro evaluation of olive and grape based natural extracts as potential preservatives for food. Inno Food Sci Emerg Technol 9:3119.

Servili M, Esposto S, Veneziani G, Urbani S, Taticchi A, Di Maio I, Selvaggini R, Sordini B, Montedoro GF, 2011. Improvement of bioactive content in virgin olive oil with an olive-vegetation water concentrate produced by membrane treatment. Food Chem 124:1308-15.

Servili M, Selvaggini R, Esposto S, Taticchi A, Montedoro GF, Morozzi G, 2004. Health and sensory properties of virgin olive oil hydrophilic phenols: agronomic and technological aspects of production that affect their occurrence in the oil. J Chromatogr A 1051:113-27.

Sperber WH, Doyle MP, 2009. Compendium of the microbiological spoilage of foods and beverages. Springer Science and Business Media LLC, New York, NY, USA.

Vinha AF, Ferreres F, Silva BM, Valentão P, Gonçalves A, Pereira JA, Oliveira MB, Seabra RM, Andrade PB, 2005. Phenolic profiles of Portuguese olive fruits (Olea europaea L.): influences of cultivar and geographical origin. Food Chem 89:561-8. 